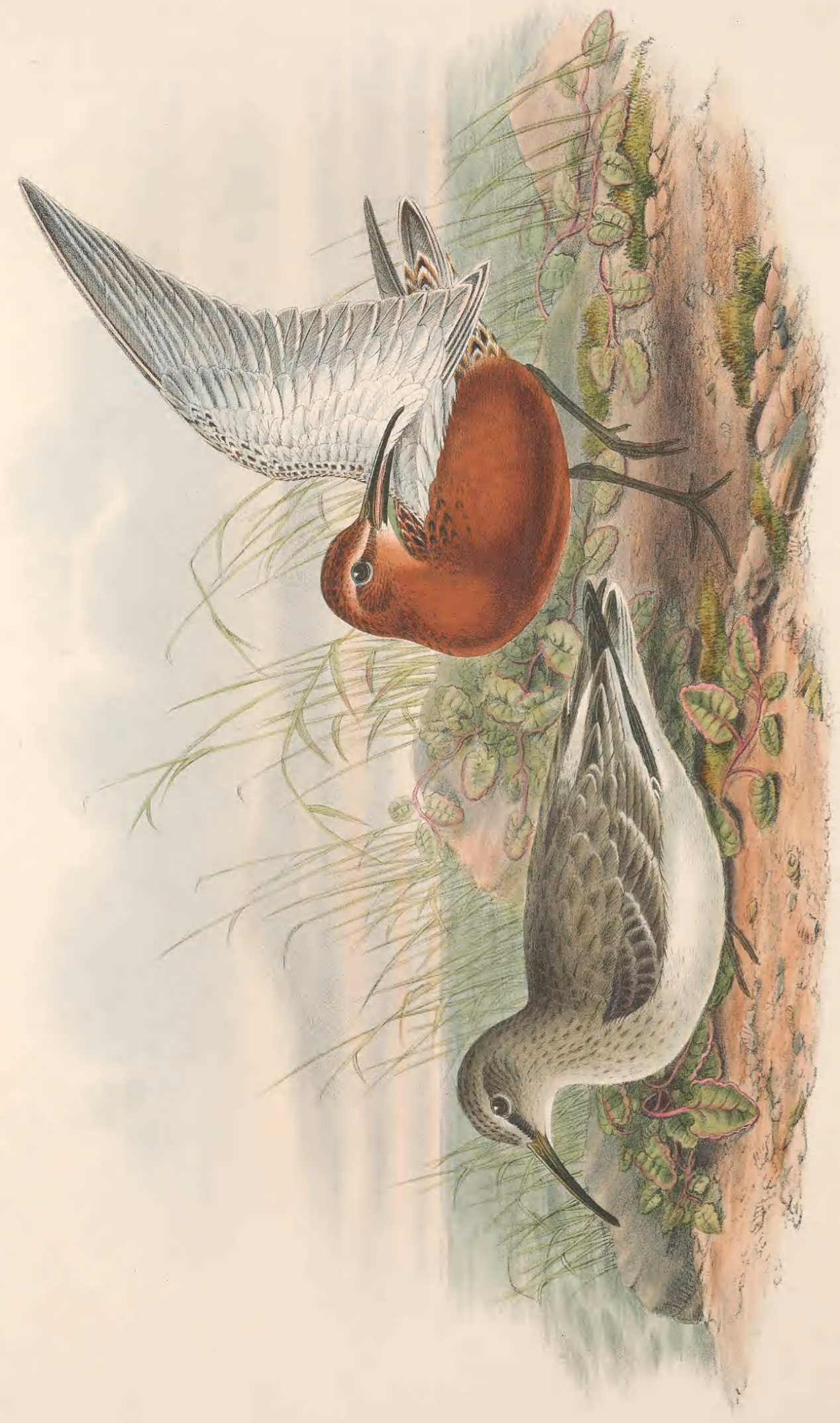

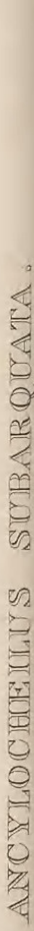




\section{ANCYLOCHEILUS SUBARQUATA.}

\section{Curlew Sandpiper.}

Scolopax subarquata, Güld. Comm. Petrop., tom. xix. p. 471.

africanus, Gmel. edit. Linn. Syst: Nat., tom. i, p. 655.

Dethardingii, Bechst. Tr. of Lath. Syn., tom. v. p. 139, tab. 123.

Numenius subarquata, Bechst. Naturg. Deutschl., tom. iv. p. 135.

pygmaeus, Bechst. ibid., p. 148.

africanus, Lath. Ind. Orn., vol. ii. p. 712.

ferrugineus, Wolf \& Meyer, Taschenb. Deutschl. Vög., tom. ii. p. 356.

Tringa pygmea, Leach, Syst. Cat. of Indig. Mamm. and Birds in Brit. Mus., p. 30

subarquata, Temm. Man. d'Orn., 1815, p. 393.

falcinella, Pall. Zooy. Rosso-Asiat., tom. ii. p. 188

ferruginea, Brünn. Orn. Bor., no. 180.

- islandica, Retz. edit. Linn. Faun. Suec., p. 192.

Pelidna subarquata, Cuv., Brehm, Vög. Deutschl., p. 657.

macrorhynchos, Brehm, Vög. Deutschl., p. 657.

Ancylocheilus subarquata, Kaup, Natïrl. Syst., p. 50.

subarquatus, Loche, Cat. des Mamm. et Ois. obs. en Algérie, p. 130.

THrs elegant species, which is trivially called Pigmy Curlew and Curlew Sandpiper, is neither scarce nor common in the British Islands, but is more abundant at some seasons than at others. Generally speaking, it is adults in their light or winter dress, and the young in the mottled plumage of immaturity, that are seen during the autumnal months, and the red or nuptial-costumed birds that occur in spring. It is the remarkable coloration of the plumage at this latter season, and the white rump at all times, that distinguish this species from the Dunlin and all others of the smaller Tringine, and constitute probably one of the reasons why Dr. Kaup assigned to it a new generic appellation, that of Ancylocheilus. That it does not breed in the British Islands is almost certain; for we have no evidence of its eggs having ever been found herein; neither is it precisely known to what country it proceeds for that purpose-most probably, as is believed, to the high northern regions, to which it is supposed the red-plumaged birds, which pass us in spring, are migrating. Temminck, it is true, states that it breeds occasionally in Holland, and deposits four or five eggs of a yellowish colour spotted with brown; but this requires confirmation. With us in England, as also in Ireland and Scotland, it is frequently seen associated with the strand-loving Dunlin and the Ring-Dottrel ; of this I have positive evidence from a circumstance which will never occur to me again, and seldom to any one else. It is now many years ago since I was collecting birds on the sandy sea-shore, on the coast of Kent, when a flock of shore-birds winged their way past me with their usual rapidity of flight; with the quickness of thought I fired into the middle of the flock; and three birds, and three only, dropped to my shot; on picking them up, one proved to be a Curlew Sandpiper, another a Ring-Dottrel, and the third a Dunlin, of which species I had imagined the flock to solely consist.

That the Curlew Sandpiper is of a very wandering disposition, and widely spread over the earth's surface, is most certain; for not only is it found in all suitable portions of Europe, but over the greater part of Asia, the islands of Sumatra, Java, and Australia. It is also abundant in many parts of North America, where, as in this country, it migrates northward in spring, and on its return visits Mexico, and probably proceeds still further in a southerly direction. It has been observed in North Africa; and there are records of its occurrence in the southern division of that continent.

The general contour of the Curlew Sandpiper is very elegant, its flight is exceedingly swift, and its actions on the ground are equally quick and animated; indeed it may be regarded as one of the most attractive of the group of birds with which it is associated.

Although noticed by every ornithologist who has written on our strand-birds, little has been recorded in this or any other country respecting its habits. Mr. Stevenson, in his 'Birds of Norfolk,' merely says, " this species is not unfrequently met with on our coast both in spring and autumn, and more particularly at the latter season. From my own observations, more specimens seem to be obtained in September and October than at any other time. Messrs. Sheppard and Whitear remark that it is more solitary than the Dunlin, not more than a pair being seen together, and is a stupid bird, suffering a boat to approach close to it. At Blakeney Mr. Dowell describes them as 'not very rare, occurring for the most part singly, amongst flocks of Dunlins, and are easily distinguishable by their gait and longer bill and conspicuous white tail-coverts.' 
Examples in the rich red plumage of the breeding-season are occasionally met with either late in spring or on their return from their breeding-grounds at the close of summer. Yarrell, who was well acquainted with our Norfolk coast, says :- 'I have obtained this bird in June, in the height of its summer plumage, from Norfolk, and have seen the young from the same locality early in July.' There is, of course, no reason to suppose that this species has ever remained to breed in this country; and the young birds above referred to must have commenced their southward passage thus early with their parents, which supposition agrees with the statement of Messrs. Gurney and Fisher, that they arrive 'about the end of July.',

Macgillivray, writing of the bird in Scotland, says :- "Although this species is very uncommon along our shores, it is probably not of so very rare occurrence as it is generally supposed to be, inattentive observers and sportsmen being apt to confound it with the Dunlin. It arrives in small flocks on the shores of the Firth of Forth in the beginning of September, and is occasionally met with at the mouth of the Esk, at Musselburgh. Generally mingling with the Dunlins, it is hardly distinguishable from them, but when seen apart is observed to have precisely the same habits as to its mode of searching the sands and mud for food, which it does by walking or running according to occasion, and patting or probing in them for small worms and other marine animals, along with which it swallows fragments of quartz and other mineral substances. Its flight is rapid and light; its ordinary cry a shrill scream, differing from the cry of the Dunlin."

Thompson says it is a regular autumnal migrant to the north of Ireland, where in winter it is of rare occurrence. September is its favourite month in Belfast Bay: the earliest arrival noted is the 25th of August; before the end of September its departure is usually taken; and it rarely remains until the end of October.

"The numbers vary much in different years. In 1838 they were remarkably scarce. In the autumn of 1837 they were more common than usual, and numbers were shot; a flock of about twenty was once seen, and out of a party of eight six were killed at one discharge. My informant distinguishes this species from the Dunlin, when on the ground, by its superior size-in flight, from the lower part of the back being white -or by its call, which is very different from that of its congener, and is said more to resemble that of the Turnstone than of other shore-birds. In 1839 they were more plentiful than ever before known, and arrived before the ordinary time, a couple having been shot on the 2 nd of September. On the 7 th of that month a flock of from thirty to forty appeared; and they increased until the 21st, when not less than a hundred were seen in company with a large body of Dunlins, though generally, when a number are together, they do not associate with other species. Occasionally about fifty or sixty would rise together from one extremity of the flock, and, after flying about for a short time, would alight with the others. The noise produced by their calls, especially when on wing, was very great. This large body subsequently proved to have been collected together for migration, as they took their departure on that day from the bay, and not one was seen again during that season. They usually keep to the shores of the bay; but in 1836 they frequented the river Lagan, within flow of the tide at high water, in flocks. On the 6th of the latter month I observed nine in company busily feeding at the edge of the river at Ormeau Bridge ; in the following year also, they frequented the tidal portion of the river."

Mr. Wright states that the Curlew Sandpiper is common in spring and autumn in Malta; Lord Lilford, that it occurs in Corfu occasionally in great numbers, and generally in full breeding-plumage, about the end of May; Mr. Simpson, that a muddy ditch near Mesolonghi is a favourite resort in spring; Mr. Howard Saunders notes it as common in winter in Southern Spain, and the Rev. A. C. Smith in Portugal; and in Italy Dr. Henry Giglioli informs us that Ancylocheilus subarquata, " in full nuptial dress, is brought alive in large numbers to the market at Pisa ; it is caught with nets, and thrives very well in captivity. I kept nine or ten, for about three months, in a small enclosed space in a garden, where they had a little pool of water; I fed them on bread and chopped meat, which they ate readily; and they were brisk and active all the while I kept them, the males constantly fighting together just as Ruffs do."

Mr. Layard notes that a living example, in full breeding-dress, was captured near Hope Town, South Africa, on the 26th of April; and Mr. Gurney, that it frequents the Bay of Natal in considerable flights; Von Heuglin found it on the Red Sea from July to September in its summer dress, and young birds alone and in small flocks, and between Bab-el-Mandeb and the Somali coast, in the winter dress, in October and November. It was obtained in Palestine by the Rev. H. B. Tristram; Captain Irby found it in Oudh and Kumaon during the cold season, in very large flocks, on the sandbanks of the rivers Gogra and Choka; and Mr. Jerdon states that it is found throughout India, is rare towards the south, but common about Calcutta and in the north of India generally.

The Plate represents two birds, of the size of life-one in the plumage of summer, the other in that of winter. The plant is the Beta maritima, Linn. 


\section{$2 \mathrm{BHL}$ Biodiversity Heritage Library}

Gould, John. 1873. "Curlew Sandpiper, Ancylocheilus subarquata [PI. 68]." The birds of Great Britain 4, -. https://doi.org/10.5962/p.324024.

View This Item Online: https://www.biodiversitylibrary.org/item/221609

DOI: https://doi.org/10.5962/p.324024

Permalink: https://www.biodiversitylibrary.org/partpdf/324024

\section{Holding Institution}

Smithsonian Libraries

\section{Sponsored by}

Biodiversity Heritage Library

\section{Copyright \& Reuse}

Copyright Status: Public domain. The BHL considers that this work is no longer under copyright protection.

This document was created from content at the Biodiversity Heritage Library, the world's largest open access digital library for biodiversity literature and archives. Visit BHL at https://www.biodiversitylibrary.org. 